\title{
CHEMOTHERAPY VERSUS BEST SUPPORTIVE CARE IN STAGE IV NON-SMALL CELL LUNG CANCER, NON METASTATIC TO THE BRAIN
}

Agnaldo Anelli, Candice A. A. Lima, Riad N. Younes, Jefferson L. Gross and

Ricardo Fogarolli

RHCFAP/3036

ANELLI A et al. - Chemotherapy versus best supportive care in stage IV non-small cell lung cancer, non metastatic to the brain.

Rev. Hosp. Clín. Fac. Med. S. Paulo 56(2):53-58, 2001.

Stage IV non-small cell lung cancer is a fatal disease, with a median survival of 14 months. Systemic chemotherapy is the most common approach. However the impact in overall survival and quality of life still a controversy.

Objectives: To determine differences in overall survival and quality of life among patients with stage IV non-small cell lung cancer non-metastatic to the brain treated with best supportive care versus systemic chemotherapy.

Patients: From February 1990 through December 1995, 78 eligible patients were admitted with the diagnosis of stage IV nonsmall cell lung cancer . Patients were divided in 2 groups: Group A ( $\mathrm{n}=31$ - treated with best supportive care ), and Group B ( $\mathrm{n}=47$ - treated with systemic chemotherapy).

Results: The median survival time was 23 weeks (range 5 - 153 weeks) in Group A and 55 weeks (range $7.4-213$ weeks) in Group B ( $\mathrm{p}=0.0018)$. In both groups, the incidence of admission for IV antibiotics and need of blood transfusions were similar. Patients receiving systemic chemotherapy were also stratified into those receiving mytomycin, vinblastin, and cisplatinum, $\mathrm{n}=25$ and those receiving other combination regimens (platinum derivatives associated with other drugs, $n=22$ ). Patients receiving mytomycin, vinblastin, and cisplatinum, $n=25$ had a higher incidence of febrile neutropenia and had their cycles delayed for longer periods of time than the other group. These patients also had a shorter median survival time (51 versus 66 weeks, $\mathrm{p}=0.005$ ).

Conclusion: In patients with stage IV non-small cell lung cancer, non-metastatic to the brain, chemotherapy significantly increases survival compared with best supportive care.

DESCRIPTORS: Chemotherapy. Non-small cell lung cancer. Best supportive care. Mytomycim, vinblastin and cisplatinum. Fatal disease.

Non-small cell lung carcinoma (NSCLC) is a common tumor, with approximately half a million new cases registered every year worldwide ${ }^{1}$. Thirty to $40 \%$ of all newly admitted patients present with disseminated metastatic disease with a limited or palliative role for localized surgical or radiation therapy. For patients with this advanced stage, chemotherapy (CT) is the treatment of choice in most centers.

Response rates with most regimens of chemotherapy range between $20 \%$ and $30 \%{ }^{2}$. Recently, the introduction of new agents, such as vinorelbine or the combination of cisplatinum or cisplatinum derivatives with paclitaxel, has resulted in higher response rates, reaching $60 \%$ in some series ${ }^{3,4}$.

Those patients usually present a median survival of 6 months ${ }^{5}$. The impact of chemotherapy on overall survival and quality of life of patients with metastatic

From the Departments of Clinical Oncology, Thoracic Surgery and Radiation Oncology Hospital do Câncer, Fundação Antônio Prudente.
NSCLC, as opposed to best supportive care solely, is still widely debated. Several studies have been published showing a small, although statistically significant, survival advantage for patients treated with chemotherapy ${ }^{6-9}$. Metaanalyses and randomized studies ${ }^{10-13}$ have demonstrated a clear benefit following systemic treatment, with one of them reaching a survival advantage of 15 weeks ${ }^{14}$. A subsequent study by the same center showed reduced overall medical costs for patients receiving chemotherapy, mainly when less expen- 
sive regimens were administered ${ }^{15}$. Other studies, however, did not report any advantageous trend for chemotherapy ${ }^{2}$.

The present study evaluates clinical outcomes of patients with stage IV NSCLC, as well as the impact of different treatment modalities.

\section{PATIENTS AND METHODS}

A retrospective analysis was performed using a prospective database. To obtain a minimum follow-up of 5 years, the records were reviewed from February 1990 to December 1995, with histologically proven stage IV NSCLC and with no demonstrable central nervous system metastases on CT scan. The treatment modality of each individual patient was identified and registered (chemotherapy or best supportive care), as was the clinical outcome.

Study targets were defined as:

1. Survival analysis for both groups.

2. Assessment of quality of life, according to the following criteria: days of in hospital treatment, days of intravenously administered antibiotics, necessity for blood and blood derivative transfusion, and number of febrile neutropenia episodes.

Eighty-six consecutive patients were admitted during that period, with 8 patients being excluded from the final analysis due to loss of follow-up greater than 3 weeks after admission.

Survival time was calculated from the date of diagnosis. Logistic regression was used to adjust for and determine the significance of the effect of prognostic factors in the treatment comparison of response. Cox's proportional hazard model was used to adjust for and determine the significance of the effect of prognostic factors in the treatment comparisons of time to event analyses (survival). All significance levels were two sided ${ }^{16}$.

\section{RESULTS}

Thirty-one patients were treated with best supportive care - BSC (Group A), while 47 patients received chemotherapy and best supportive care - CT (Group B). Patient characteristics of the two groups are displayed in table 1.

BSC was defined as treatment of pain, cough, dyspnea, palliative radiotherapy, infections, and pleural effusions.

Both groups were comparable for age and sex. On the other hand, performance status was significantly lower in patients of Group A, with $26 \%$ of patients presenting with important health problems, compared to $4 \%$ in Group B. Patients in Group A more often underwent palliative radiotherapy $(\mathrm{n}=17$ $54.8 \%$ ), than patients of Group B $(n=26,55.3 \%)$, although the difference was not significant.

Histology was significantly different between groups: Squamous cell carcinoma was more frequently diagnosed in Group A, while adenocarcinoma was the most frequent histology in Group B.

Chemotherapy was not indicated in patients of Group A for the following reasons:

1. Palliative radiotherapy $(n=9)$.

2. Patient's decision $(n=5)$.

Table 1 - Patient characteristics.
3. Medical decision to observe asymptomatic patients with ECOG performance status of 3 and 4 $(n=8)$.

4. Infection on admission $(n=1)$.

5. Immediate necessity for palliation $(n=5)$ until significant symptoms.

6. Limiting comorbidity (cardiac failure, $n=1$, renal failure, $n=2$ ).

Median survival for Group A was 23 weeks, significantly lower than the 55 weeks for Group B ( $\mathrm{p}=0.0018)$. Figure 1 shows the overall survival curve for all patients. Figure 2 shows survival according to modality of treatment.

Patients that received chemotherapy intended to treat metastatic disease were further divided into 2 subgroups, depending on the regimen used: MVP (mitomycin, vinblastin, and cisplatinum, $n=25$ ) considered the standard treatment in the institution at that period, or other investigational chemotherapy regimens (including cisplatinum derivatives in combination with etoposide or paclitaxel, and the combination of ifosfamide, cisplatinum, and vinblastin, $\mathrm{n}=22$ ). $\mathrm{Pa}$ tients that received MVP had a 51week median survival, significantly lower than the 66 weeks for the other group. Figure 3 shows the survival

\begin{tabular}{lcc}
\hline & $\begin{array}{c}\text { Best Supportive Care } \\
\mathrm{n}=31\end{array}$ & $\begin{array}{c}\text { Chemotherapy } \\
\mathrm{n}=47\end{array}$ \\
\hline Age & Median 62 years & Median 57 years \\
\hline Sex & $\begin{array}{c}\text { Male }-22(71 \%) \\
\text { Female - } 9(29 \%)\end{array}$ & $\begin{array}{c}\text { Male }-32(68 \%) \\
\text { Female }-15(32 \%)\end{array}$ \\
\hline Performance Status* & 3 and $4-8(26 \%)$ & 3 and $4-2(4 \%)$ \\
\hline Chest Radiotherapy & $17(54.8 \%)$ & $26(55.3 \%)$ \\
\hline Squamous Cell & $15(48 \%)$ & $11(23 \%)$ \\
Carcinoma & $8(26 \%)$ & $30(64 \%)$ \\
Adenocarcinoma & $8(26 \%)$ & $6(12 \%)$ \\
Others $\dagger$ & &
\end{tabular}

*ECOG Performance Status; $\uparrow$ Others defined as: Large Cell Carcinoma and Undifferentiated Carcinoma. 


\section{Overall Survival}

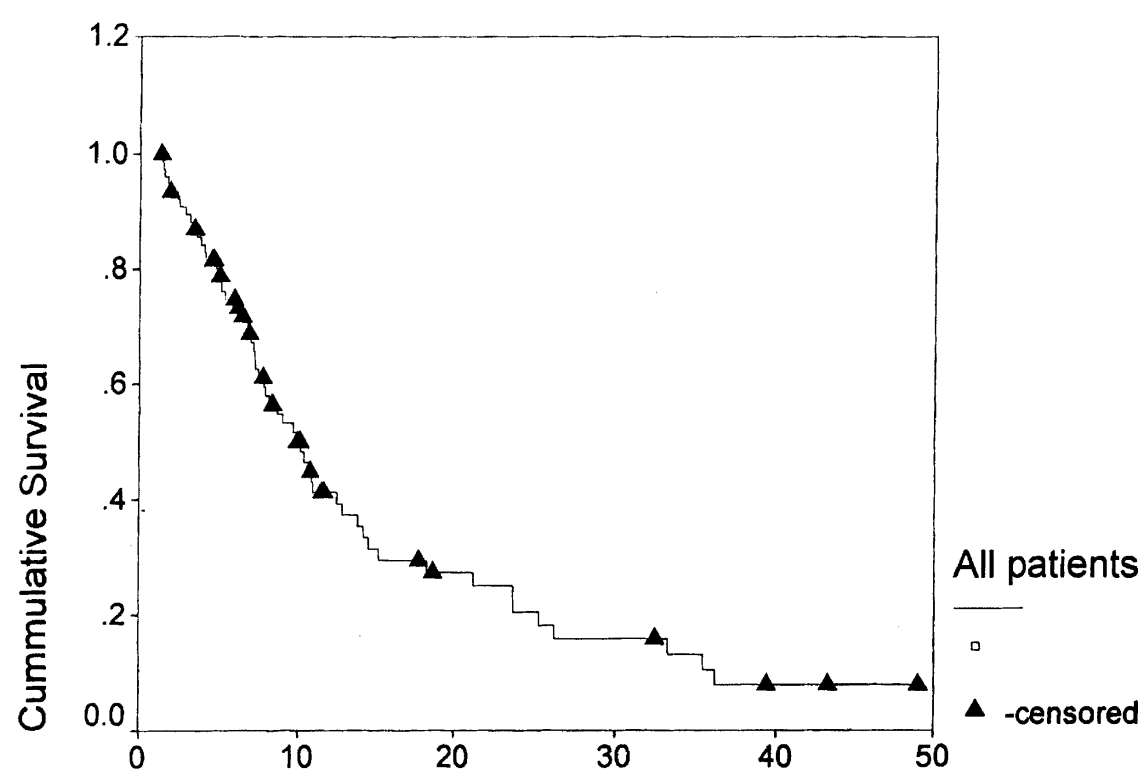

Follow-up (months)

Figure 1 - Overall survival for all patients.

\section{Survival}

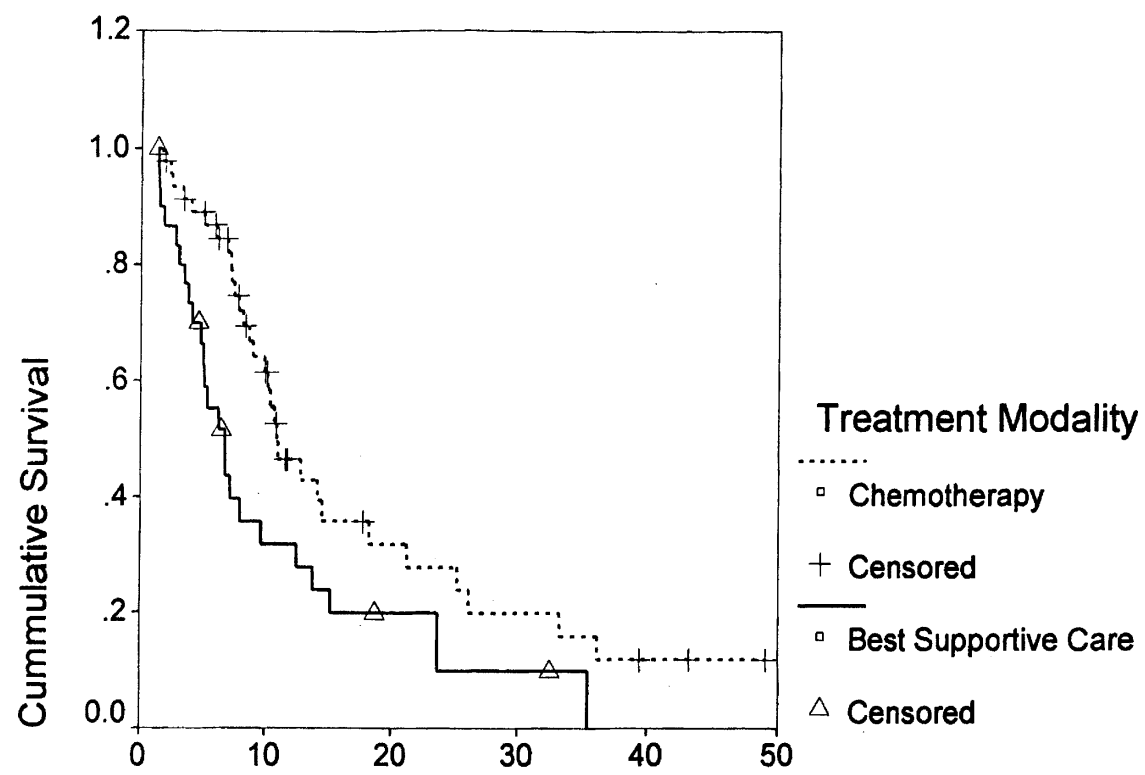

Follow-up (months)

Figure 2 - Survival according to the treatment modality. curves according to the chemotherapy regimen.

The overall response rate for chemotherapy was $19.1 \%$, with no complete response: nine patients had a partial objective response (19.1\%), 21 patients (44.7\%) had stable disease, and 17 patients $(36.2 \%)$ had progressive disease. Figure 4 shows survival curves for patients according to type of response.

Performance status on admission rendered the two groups too heterogeneous for a meaningful evaluation. However, when patients with ECOG PS 3-4 were excluded from both groups, survival was still significantly greater for patients treated with chemotherapy (51.2 weeks), compared to the other group (33.8 weeks), $\mathrm{p}=0.002$.

Patients in Group A had a median in-hospital treatment time of 13 days, similar to 16.5 days in Group B. No significant differences were observed for antibiotic administration and transfusion episodes. Table 2 displays the corresponding data.

Episodes of neutropenia occurred exclusively in MVP patients ( $\mathrm{n}=3$ cycles). This chemotherapeutic regimen was associated with significant delays between cycles due to significant toxicity.

\section{DISCUSSION}

For patients with non-small cell lung cancer (NSCLC), the prospect of long-term survival is directly related to the surgical resectability of the primary tumor. At initial presentation, the great majority of NSCLC have either locally advanced inoperable disease, stage IV metastatic disease, or comorbid medical conditions that render them unsuitable for surgical intervention. Because of that, the vast majority of patients with NSCLC are candidates for systemic treatment with or without radiotherapy. A large number of clinical trials exploring combination chemotherapy in NSCLC have been per- 


\section{Survival}

\section{Type of Chemotherapy}

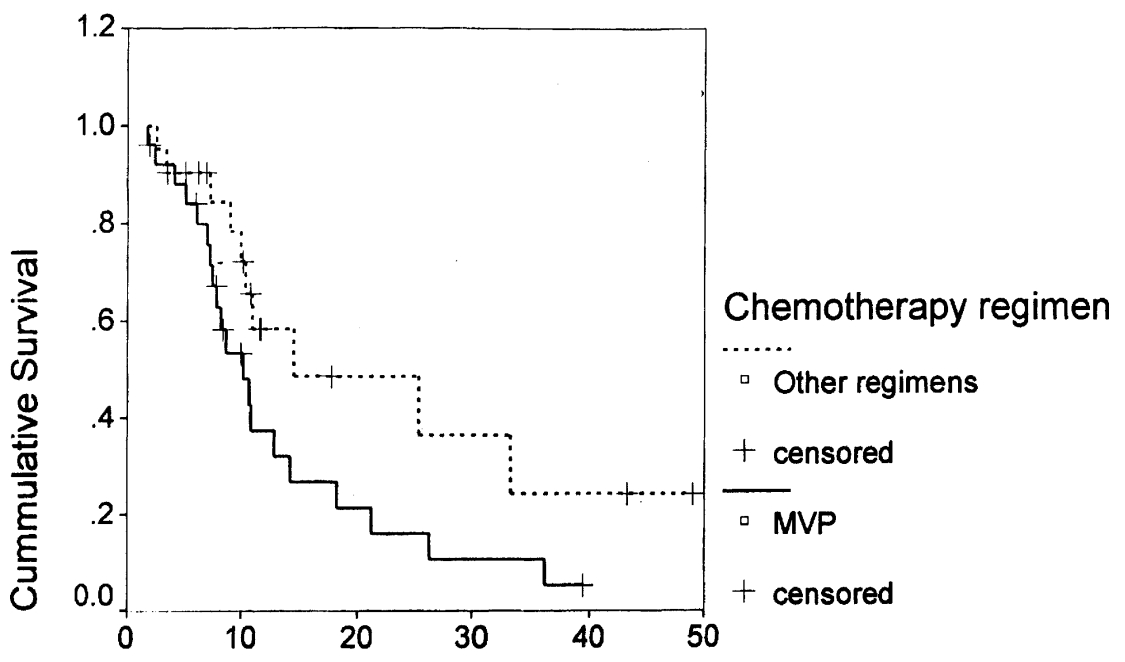

Follow-up (months)

Figure 3 - Survival according to the type of chemotherapy (MVP or other regimens).

\section{Survival}

\section{Without patients with PS 3 and 4}

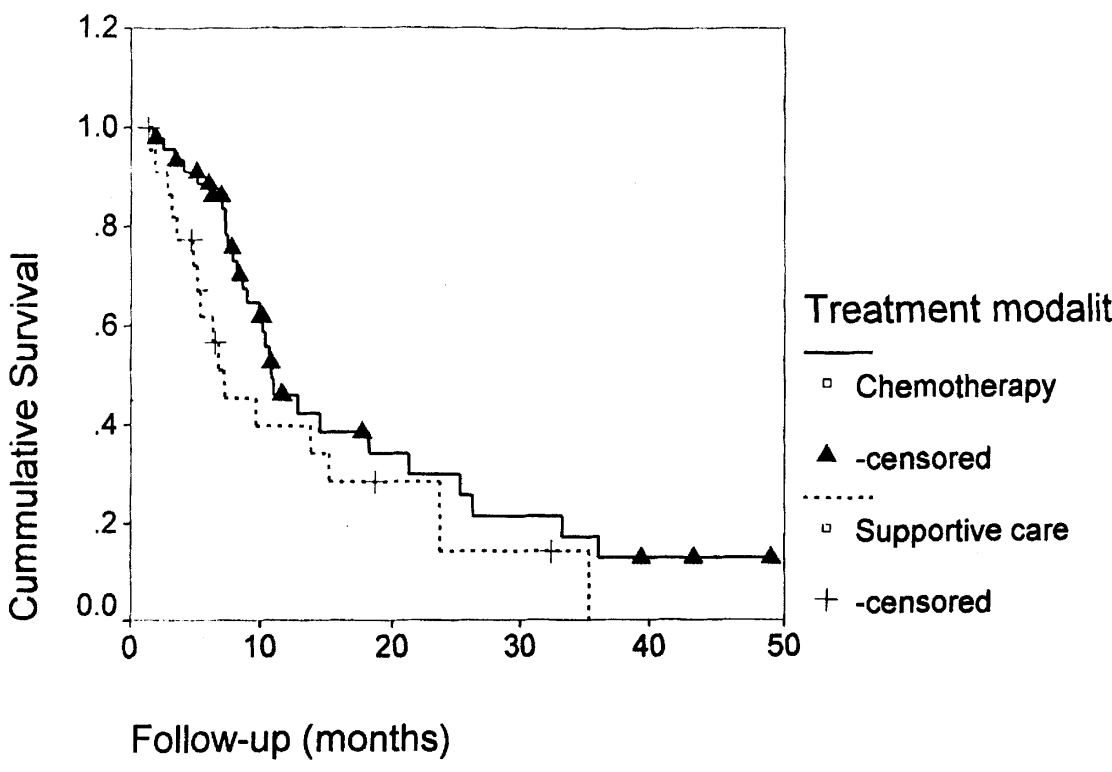

Figure 4 - Survival according to the type of response to chemotherapy. formed. Several conclusions can be drawn from a review of phase II and phase III randomized trials performed in NSCLC patients ${ }^{15,17,18}$ : (1) overall response rates usually range from $20 \%$ to $30 \%$; (2) complete responses are an exception; (3) the majority of trials are based on the combination of a cisplatinum derivative and other drugs; (4) the overall impact of combination chemotherapy regimens on improved survival is modest; (5) the majority of patients rarely survive longer than 18 months, and most combination chemotherapy regimens are associated with some type of toxicity (mainly nausea, vomiting, and febrile neutropenia).

Although most of the trials of chemotherapy in NSCLC show only a marginal improvement in medial length of survival, the majority do show a trend toward improved overall survival when compared with best supportive care (BSC). In a prospective randomized trial conducted by Italian investigators ${ }^{12}, 102$ patients with NSCLC were randomized to receive a combination of cisplatin, cyclophosphamide, and vinblastin or to receive BSC. In the group of patients receiving chemotherapy, the median overall survival was 8.5 months versus 4.0 months in the group receiving BSC $(\mathrm{p}<.0001)$.

In another randomized trial conducted by the National Cancer Institute of $\mathrm{Canada}^{13}$, patients were randomized to receive two different chemotherapy regimens (vindesin and cisplatin or cyclophosphamide, doxorubicin, and cisplatin) or BSC. Patients on the chemotherapy arms had a median overall survival of 32.6 and 24.7 weeks respectively versus 17 weeks for the group treated with $\mathrm{BSC}(\mathrm{p}=0.05)$.

However, in two other studies, including a large randomized trial involving 188 patients, no statistically significant difference in survival was observed, although an advantage for chemotherapy was observed in some patients subsets ${ }^{17,18}$. 
Table 2 - Chemotherapy and quality of life.

\begin{tabular}{lcc}
\hline & $\begin{array}{c}\text { Best Supportive Care } \\
\mathrm{n}=31\end{array}$ & $\begin{array}{c}\text { Chemotherapy } \\
\mathrm{n}=47\end{array}$ \\
\hline In-hospital Treatment & $\begin{array}{c}\text { Median 13 days } \\
\text { (Range 1-70 days) }\end{array}$ & $\begin{array}{c}\text { Median 16.5 days } \\
\text { (Range 1-57 days) }\end{array}$ \\
\hline Antibiotic Administration & $\begin{array}{c}\text { Median 6 days } \\
\text { (Range 2-26 days) }\end{array}$ & $\begin{array}{c}\text { Median 5 days } \\
\text { (Range 2-27 days) }\end{array}$ \\
\hline Blood Transfusion & Median 1 unit \\
(Range 0 - 8 units) & $\begin{array}{c}\text { Median 2 units } \\
\text { (Range 0 }-16 \text { units) }\end{array}$ \\
\hline Febrile Neutropenia & No episodes & 3 episodes \\
\hline
\end{tabular}

In our study, the median survival for patients receiving BSC was 23 weeks, significantly lower than 55 weeks for the group receiving chemotherapy ( $\mathrm{p}=0.002)$. Our data shows that even when patients with a low ECOG performance status are excluded from analysis, overall survival is still higher in patients treated with chemotherapy compared to patients treated with best supportive care only.
Measurement of quality of life remains an important goal for investigators treating patients with metastatic lung cancer, since chemotherapy may have a salutary or negative impact independent of how the survival curves look $^{19}$. In our study, the toxicity in the group treated with chemotherapy was mild and tolerable. Patients treated with BSC had a median in-hospital treatment time of 13 days, similar to 16.5 days in the group treated with chemotherapy. We did not observe any significant differences in terms of antibiotic administration and transfusion episodes.

The present study, which included a balanced and adequate number of patients, indicates that patients with metastatic non-small-cell lung cancer can benefit from chemotherapy with a statistically significant increase in survival compared to best supportive care.

Whether the gains in life expectancy are worth potential losses in quality of life from treatment side effects is largely an individual patients choice. The major challenge for oncologists would be to identify and develop properly designed instruments to collect information on how much the expected benefit is valued by the patients and to involve patients in the decision of treatment options, reflecting their own preferences.
ANELLI A e col. - Quimioterapia versus melhor tratamento de suporte em câncer de pulmão estádio clínico IV não metastático para o sistema nervoso central. Rev. Hosp. Clín. Fac. Med. S. Paulo 56 (2):5358, 2001.

O câncer de pulmão de células não pequenas em estádio IV é uma doença fatal, com uma sobrevida mediana de seis meses. Quimioterapia é a abordagem mais freqüente, apresentando um impacto na sobrevida controverso e questionável alteração na qualidade de vida.

Objetivos: Comparar o impacto na sobrevida global e na qualidade de vida em pacientes portadores de câncer de pulmão de células não pequenas, estádio IV, tratados com suporte clínico ou quimioterapia.

Pacientes: Entre fevereiro de 1990 e dezembro de 1995, 78 pacientes (pts) portadores de câncer de pulmão de células não pequenas estádio IV foram admitidos. Os pacientes foram divididos em dois grupos: grupo A ( $\mathrm{n}=31$ tratados com suporte clínico) e grupo B ( $n=47$, tratados com quimioterapia).

Resultados: A sobrevida mediana no grupo tratado com suporte clínico foi de 23 semanas (variando de 5-153 semanas) e de 55 semanas no grupo tratado com quimioterapia (variando de 7,4 a 213 semanas), p= 0,0018 - Quiquadrada. Em ambos grupos, a incidência de internações hospitalares para a administração intravenosa de antibióticos e hemoderivados foi similar. Pacientes recebendo quimioterapia, foram estratificados entre àqueles que receberam mitomicina, vinblastina e cisplatina, $n=25$ e àqueles recebendo outros regimes (derivados de platina, associados à outras drogas, $\mathrm{n}=22$ ). $\mathrm{Pa}$ - cientes recebendo mitomicina, vinblastina e cisplatina, $n=25$ apresentaram uma incidência mais alta de neutropenia febril e tiveram atrasos mais longos entre os ciclos de quimioterapia, quando comparados aos pacientes do outro grupo. Pacientes recebendo mitomicina, vinblastina e cisplatina, $\mathrm{n}=25$, também apresentaram uma pior sobrevida mediana (51 versus 66 semanas, $\mathrm{p}=0,005$ - Qui-quadrado).

Conclusões: Em pacientes com câncer de pulmão de células não pequenas, estádio IV, não metastático para os pulmões, o uso de quimioterapia aumenta a sobrevida de maneira estatisticamente significativa, quando comparado aos cuidados de suporte.

DESCRITORES: Quimioterapia. Câncer de pulmão de células não pequenas. Suporte clínico. Metomicina, vinblastina e cisplatina. Doença fatal. 


\section{REFERENCES}

1. LANDIS SH, MURRAY T, BOLDEN S et al. - Cancer statistics, 1998. CA. Cancer J Clin 1998; 48:6-29.

2. SHEPHERD FA. - Treatment of advanced non-small cell lung cancer Semin Oncol 1994; 21 [ Suppl. 7]: 7.

3. LANGER CJ, LEIGHTON JC \& COMES RL. - Paclitaxel and Carboplatin in combination in the treatment of advanced non-small cell lung cancer: a phase II toxicity response and survival analysis. J Clin Oncol 1995 13: 1860

4. VAFAI D, ISRAEL V \& ZARETZKY S - Phase I/II trial of combination Carboplatin and Taxol in non-small cell lung cancer (NSCLC). [abstract]. Proc Am Soc Clin Oncol 1995; 14: 352.

5. MOUTAIN CF - A new international staging system for lung cancer. Chest 1986; 89: 225S.

6. GANZ PA, FIGLIN RA, HASKELL CM et al. - Supportive care versus supportive care and combination chemotherapy in metastatic nonsmall cell lung cancer - does chemotherapy make a difference? Cancer 1989; 63: 1271 - 8

7. LE CHEVALIER $T$ - Chemotherapy for advanced NSCLC - Will metaanalysis provide the answer? Chest 1996; 109: 107s - 9s.

8. LEUNG WT, SHIU WCT, PANG JCK et al. - Combined chemotherapy and radiotherapy versus best supportive care in the treatment of inoperable non-small cell lung cancer. Oncology 1992; 49: 321 - 6.

9. SOUQUET PJ, CHAUVIN F, BOISSEL JP et al. - Polychemotherapy in advanced non-small cell lung cancer: a meta-analysis. Lancet 1992; 342: 19 - 21 .

10. MARINO P, PAMPALLONA S, PREATONI A et al. - Chemotherapy versus supportive care in advanced non-small cell lung cancer - results of a meta-analysis of the literature. Chest 1994; 106: 861 - 5 .

11. CORMIER Y, BERGERON D, FORGE $J$ et al. - Benefits of polychemotherapy in advanced non-small cell bronchogenic carcinoma. Cancer 1982; 50: 845 - 9 .
12. CARTEI G, CARTEI F, CANTONE A et al. - CisplatinCyclophosphamide-Mytocin combination chemotherapy with supportive care versus supportive care alone for treatment of metastatic non-small cell lung cancer. J Natl Cancer Inst 1993; 85: $794-800$

13. THONGPRASERT S, SANGUANMITRA P, UMSAWASDI T Relationship Between Quality of Life and Clinical Outcomes in Advanced Non-Small Cell Lung Cancer: Best Supportive Care (BSC) versus BSC plus Chemotherapy. Proc Am Soc Clin Oncol 1995; 14: 1093. (Abstract).

14. RAPP E, PATER JP, WILLAN A et al. - Chemotherapy can prolong survival in patients with advanced non-small cell lung cancer report of a canadian multicenter randomized trial. J Clin. Oncol 1988; 6: 633 - 41

15. JAAKKIMAINEN L, GOODWIN PJ, PATER J et al. - Counting the costs of chemotherapy in a National Cancer Institute of Canada randomized trial in non-small-cell lung cancer. J Clin Oncol 1990; 8: $1301-9$.

16. PETO R, PIKE MC \& ARMITAGE P - Design and analysis of randomized clinical trials requiring prolonged observation of each patient. Br J Cancer 1977; 35:1-39.

17. WOODS RL, WILLIANS CJ \& LEVI J - A randomized trial of cisplatin and vindesin versus best supportive care in non-small-cell lung cancer. Br J Cancer 1990; 61:608-11.

18. CELLERINO R, TUMMARELLO D \& GUIDI F - A randomized trial of alternating chemotherapy versus best supportive care in advanced non-small-cell lung cancer. J Clin Oncol 1991; 9:1453-61.

19. FELD R - Quality of life in patients with non-small-cell lung cancer treated with hemotherapy. Eur J Cancer Clin Oncol 1987; 23 : $357-9$.

Received for publication on October 27, 2000. 